\title{
Pengembangan Masyarakat Desa Plumbon Gambang Kecamatan Gudo Kabupaten Jombang dengan Pendekatan Participatory Rural Apraissal dalam Percepatan Pembangunan Desa
}

\author{
Belinda Ulfa Aulia ${ }^{1}$ \\ Eko Budi Santoso ${ }^{2}$ \\ Arwi Yudhi Kuswara ${ }^{3}$ \\ ${ }^{1}$ Pengajar Jurusan Perencanaan Wilayah dan Kota, Institut Teknologi Sepuluh Nopember \\ b3ltown@gmail.com
}

\begin{abstract}
ABSTRAK
Permasalahan pembangunan pada kawasan perdesaan salah satunya disebabkan karena minimnya partisipasi masyarakat dalam perencanaan pembangunan. Desa Plumbon Gambang-Diwek-Jombang merupakan salah satu potret kawasan perdesaan yang ingin melakukan percepatan pembangunan kawasan desa dengan cara mengetahui kebutuhan pembangunan desa berdasarkan masukan langsung dari masyarakat. Melalui artikel ini akan dikaji apa yang menjadi kebutuhan pembangunan desa secara tepat dibatasi pada kebutuhan pembangunan terkait aspek fisik. Untuk mendapatkan informasi yang akurat maka digunakan pendekatan Participatory Rural Appraisal (PRA) dengan menggunakan teknik participatory mapping. Dengan menggunakan teknik tersebut diharapkan dapat terrumuskan kebutuhan pembangunan desa berdasarkan asas partisipatif kemudian selanjutnya dapat ditentukan prioritas kebutuhan pembangunan desa. Dengan memahamkan masyarakat desa atas proses partisipatif maka selanjutnya dapat digaris bawahi hal-hal yang dianggap penting dalam mengaplikasikan participatory mapping untuk menjawab kebutuhan pembangunan desa.
\end{abstract}

Kata Kunci : pengembangan masyarakat, Participatory Rural Appraissal (PRA), participatory mappig 


\section{PENDAHULUAN}

Undang Undang Nomor 6 Tahun 2014 Tentang Desa mengamanatkan adanya kemandirian dan partisipasi masyarakat desa dalam pembangunan. Desa memiliki kewenangan luas sebagai daerah otonom untuk mengelola wilayahnya dalam pembangunan. Peran desa sangat penting dalam mewujudkan pembangunan pada tataran nasional, sehingga kini masyarakat desa bukan lagi hanya berperan sebagai obyek pembangunan, melainkan sudah menjadi subyek pembangunan tersebut.

Menurut UU No. 25 tahun 2004, sistem Perencanaan Pembangunan Nasional merupakan satu kesatuan tata cara perencanaan pembangunan untuk menghasilkan rencana-rencana pembangunan dalam jangka panjang, jangka menengah, dan tahunan yang dilaksanakan oleh unsur penyelenggara negara dan masyarakat di tingkat pusat dan daerah. Perencanaan pembangunan di daerah sebetulnya tidak terpisah dari perencanaan pembangunan di tingkat nasional, sebagaimana disebutkan dalam PP No. 8 tahun 2008 (pasal 2 ayat 1). Perencanaan pembangunan pada tingkat desa merupakan suatu proses untuk menentukan tindakan masa depan yang tepat, melalui urutan pilihan, dengan memperhitungkan sumber daya yang tersedia dalam rangka peningkatan kualitas hidup dan kehidupan untuk sebesar-besarnya bagi kesejahteraan masyarakat Desa.

Desa Plumbon Gambang, Kecamatan Gudo, Kabupaten Jombang, merupakan salah satu potret kawasan perdesaan yang ingin melakukan percepatan pembangunan kawasan desa dengan cara mengetahui kebutuhan pembangunan desa berdasarkan masukan langsung dari masyarakat. Desa yang memiliki keunggulan dalam bidang pertanian yang cukup baik di Kabupaten Jombang, dengan luas pertanian 127,57 Ha. Namun, saat musim penghujan sering terjadi banjir yang salah satu penyebabnya adalah kurang meksimalnya sistem jaringan irigasi. Hal ini, dapat berdampak pada terjadinya gagal panen karena air menggenangi sawah secara berlebihan. Padahal, sebagian besar mata pencaharian penduduk Desa Dusun Plumbon Gambang adalah petani, yaitu 1796 petani (Kecamatan Gudo Dalam Angka, 2015).

Dalam mengatasi permasalahan didalam masyarakat dapat menggunakan pendekatan perencanaan partisipatif. Masyarakat memiliki hak dalam proses penyusunan, dan pelaksanana pembangunan daerah untuk mewujudkan pembangunan yang berkelanjutan. Pembangunan partisipatif adalah suatu sistem pengelolaan pembangunan di desa bersama-sama secara musyawarah, mufakat, dan gotong royong yang merupakan cara hidup masyarakat yang telah lama berakar budaya di wilayah Indonesia dengan memberdayakan masyarakat setempat.

Pemberdayaan masyarakat desa merupakan upaya untuk memandirikan masyarakat desa melalui potensi yang dimiliki untuk menetapkan pilihan-pilihan kegiatan yang paling sesuai bagi kemajuannya (Sumodiningrat, 2001). Upaya pemberdayaan masyarakat desa dapat memberikan stimulasi untuk mendorong atau memotivasi individu agar memiliki kemampuan atau keberdayaan dalam memutuskan pilihan-pilihannya melalui proses dialog. Proses dialog dapat membangun kapasitas masyarakat desa dalam perumusan program-program dalam mengatasi permasalahan yang ada dimasyarakat, sehingga tujuan-tujuan pembangunan yang telah ditetapkan dapat diwujudkan pada kurun waktu yang telah ditentukan. Oleh karena itu, untuk mempercepat pembangunan Desa Plumbon Gambang, diperkulan partisipasi masyarakat desa dalam proses mencari potensi dan masalah sehingga dapat tersusun program-program pembangunan desa yang berkelanjutan. 


\section{METODE}

Sebagaimana diuraikan dalam pendahuluan, penelitian ini menggunakan participatory rural apraisal (PRA) sebagai pendekatan dalam percepatan pembangunan Desa Plumbon Gambang. Metode yang digunakan adalah focus group discussion (FGD) dengan bantuan teknik pengambilan data berupa participatory mapping atau pemetaan partisipatif.

Untuk mencapai tujuan penelitian, maka dilakukan dua sasaran, yakni (1) mengidentifikasi potensi dan masalah percepatan pembangunan Desa Plumbon Gambang Kecamatan Gudo Kabupaten Jombang dan (2) menentukan program prioritas pengembangan desa Plumbon Gambang Kecamatan Gudo Kabupaten Jombang dari segi infrastruktur. Output yang akan dihasilkan dalam kegiatan ini adalah program-program prioritas pengembangan infrastruktur dalam percepatan pembangunan Desa Plumbon gambang berdasarkan potensi dan masalah desa.

Metode participatory rural apraisal (PRA) ini digunakan untuk meningkatkan kapasitas masyarakat dalam menetapkan pilihan kegiatan yang sesuai dengan permasalahan desa dan kebutuhan masyarakat. PRA digunakan bertujuan membentuk dialog dengan kelompok pada komunitas desa untuk mengidentifikasi dan menganalisis permasalahan, kebutuhan mereka, pengetahuan dan kebiasaan mereka, perasaan dan sikap mereka, serta persepsi mereka terhadap isu-isu pembangunan yang akan diteliti (Anyaegbunam, Mefalopulos, \& Moetsa, 2004). Metode yang digunakan dalam PRA pada penelitian ini adalah metode focus group discussion (FGD) dengan bantuan teknik penggalian data berupa participatory mapping (pemetaan partisipatif).FGD adalah cara yang bagus untuk mengumpulkan orang-orang dari latar belakang atau pengalaman yang sama untuk mendiskusikan topik yang spesifik.
Kelompok diskusi dipandu oleh seorang moderator atau sekelompok fasilitator yang memperkenalkan topik diskusi dan membantu grup untuk berpartisipasi secara aktif dan natural di antara mereka (Bloor, Frankland, Thomas, \& Robson, 2002).

Sementara pemetaan partisipatif adalah proses pembuatan peta yang berusaha meperlihatkan kesatuan antara lahan dengan komunitas lokal dengan menggunakan pemahaman umum dan simbol kartografi (legenda peta) yang dikenali masyarakat lokal (Corbett, 2009). Dalam penelitian ini masyarakat memetakan potensi dan masalah yang dirasakan serta usulan kegiatan dalam pengatasi permasalahan tersebut. Participatory mapping atau pemetaan partisipatif adalah teknik inti dalam pengambilan data di masyarakat lokal. Secara umum, sebagian tahapan telah terakomodasi dalam tahapan PRA. Langkah-langkah pemetaan partisipatif secara umum adalah sebagai berikut:

a. Langkah pertama sebelum memulai pada langkah pemetaan partisipatif adalah menyiapkan checklist mengenai hal-hal yang perlu dipetakan. Hal yang perlu dipetakan dalam kegiatan ini adalah potensi dan masalah desa, serta usulan program dalam percepatan pembangunan desa.

b. Langkah kedua adalah mencari tempat yang cukup luas untuk melakukan pemetaan.

c. Setelah tempat melakukan pemetaan ditemukan, langkah ketiga adalah fasilitator menggambar satu atau dua landmark / penanda untuk menunjukkan titik semua orang berkumpul tempat proses pemetaan berlangsung.

d. Langkah keempat adalah fasilitator memandu kegiatan pemetaan kepada anggota diskusi sesuai dengan checklist yang telah dibuat.

Berdasarkan langkah-langkah pemetaan partisipatif, untuk mendapatkan hasil yang validasi memalui 
kesepakatan yang ditetapkan oleh angota diskusi. Masyarakat yang terlibat dalam kegiatan participatory rural apraisal di Desa Plumbon Gambang adalah masyarakat Desa Plumbon Gambang Kecamatan Gudo Kabupaten Jombang yang mengetahui kondisi lingkungan di masing-masing dusun. Adapun yang menjadi anggota diskusi pada proses pemetaan partisipatif adalah perangkat desa, perwakilan kelompok tani, perwakilan anggota PKK, serta RT dan RW dari Dsn. Gambang, Dsn. Keturus, Dsn. Pojok, Dsn. Juwok, dan Dsn. Plumbon.

\section{HASIL}

A. Identifikasi Potensi Dan Masalah Melalui Participatory Mapping

FGD yang dilaksanakan di Desa Plumbon Gambang diawali dengan pendataan potensi dan masalah terkait infrastruktur pengairan pertanaian. Hasilnya, warga memaparkan terkait permasalahan infratruktur pengairan pertanian. Participatory mapping digunakan pada proses ini untuk memetakan lokasi permasalahan infrastruktur pengairan pertanian di desa. Pada kegiatan FGD masyarakat Desa Plumbon Gambang menilai bahwa, Desa Plumbon Gambang memiliki potensi diantaranya :

a. Jalan Desa Plumbon merupakan jalan alternative yang menghubungkan Kabupaten Jombang dengan Kabupaten Kediri

b. Memiliki lahan pertanian yang luas

c. Telah terdapat Gapoktan, Bumdes dan Koperasi

d. Potensi komoditas pertanian dan perkebunan banyak, padi, jagung, pisang dan mangga

e. Pelatihan pengolahan hasil pertanian menjadi produk olahan makanan dan minuman dan teknologi tepat gunapun sangat banyak diberikan oleh pemerintah.

f. Plumbon Gambang terdapat sentra industri manik-manik dari kaca yang menjadi ikonnya Kabupaten Jombag, dikenal hingga mancanegara

g. Dari 121 pengusaha manik-manik bisa menyerap tenaga kerja sebanyak 1007 pekerja tetap dan 600 pekerja tidak tetap.

h. Terdapat lembaga APMA (Asosiasi Pengusaha Manik-manik dan Aksesoris)

Berdasarkan hasil FGD diperoleh informasi bahwa masalah di Desa Plumbon Gambang adalah sebagai berikut :

a. Terdapat genangan di sawah dan permukiman warga di Dsn. Gambang pada musim penghujan

b. Saluran drainase dan irigasi yang berada di Dsn. Plumbon masih kurang lebar

c. Saluran irigasi di Dsn. Pojok dan Juwok masih kurang

d. Banyaknya warga yang membuang sampah di selokan atau saluran irigasi

e. kurangnya kesadaran masyarakat untuk memelihara sapras yang ada.

f. adanya dam pembagi dan saluran air yang rusak.

g. perlunya pemerataan pembangunan drainase.

h. kurang kompaknya pemuda sehingga menimbulkan gesekan dan konflik kepentingan.

i. kurangya sarana untuk pengembangan bakat bagi generasi muda seperti alat kesenian dll

Potensi dan masalah di atas didapatkan dari hasil participatory mapping seperti yang digambarkan pada Gambar 1.
B. Penentuan Program Prioritas Pengembangan Desa Plumbon Gambang Aspek Infrastruktur. 
Dengan menentukan potensi dan masalah yang ada di Dusun Plumbon Gambang, maka masyakat dapat dengan mudah menyusun alternative programprogram pembangunan yang dapat dilaksanakan untuk percepatan pembangunan desa. Adapun programprogram pembangunan yang diusulkan masyarakat berdasarkan hasil FGD dapat dilihat pada Tabel 1.

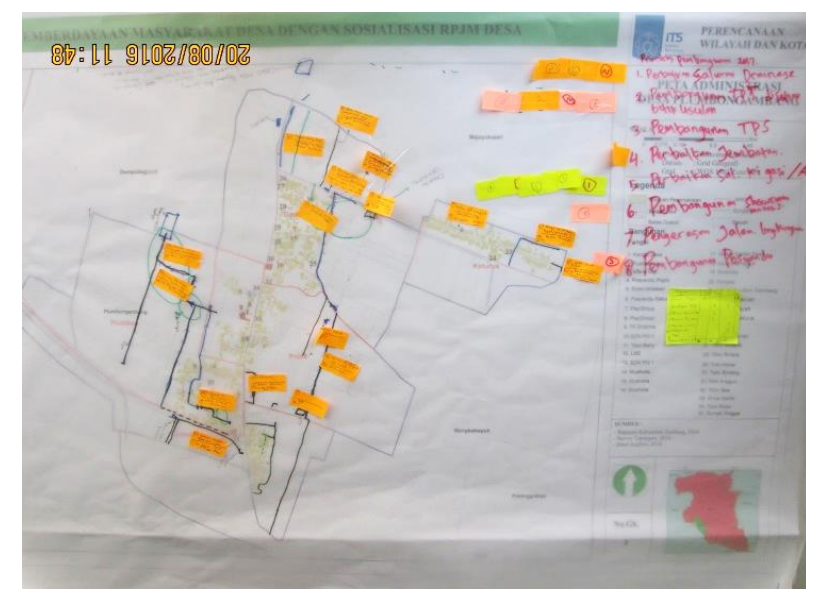

Gambar 1. Hasil Paricipatory Mapping Aspek Fisik

Sumber: dokumen penulis, 2016

Tabel 1. Usulan Program Pembangunan Infrastruktur Pengairan Pertanian

\begin{tabular}{|l|c|}
\hline \multicolumn{1}{|c|}{ Usulan Program } & Priorita: \\
\hline $\begin{array}{l}\text { Perlu perbaikan saluran irigasi /afur di dusun } \\
\text { Plumbon }\end{array}$ & 1 \\
\hline $\begin{array}{l}\text { Perlu adanya pembangunan TPT di Dusun } \\
\text { Plumbon bagian timur (dekat dengan jalan raya) }\end{array}$ & 1 \\
\hline $\begin{array}{l}\text { Perlu adanya pembangunan TPT di Dusun } \\
\text { Plumbon bagian selatan perbatasan dengan } \\
\text { Dusun Juwok }\end{array}$ & 1 \\
\hline $\begin{array}{l}\text { Perlu adanya pembangunan TPT di Dusun } \\
\text { Juwok }\end{array}$ & 1 \\
\hline $\begin{array}{l}\text { Perlu adanya pembangunan TPT di Dusun } \\
\text { Pojok }\end{array}$ & 1 \\
\hline $\begin{array}{l}\text { Perlu adanya pembangunan TPT di Dusun } \\
\text { Gambang }\end{array}$ & 1 \\
\hline $\begin{array}{l}\text { Perlu adanya pembangunan TPT di Dusun } \\
\text { Juwok perbatasan Wangkalkepuh }\end{array}$ & 2 \\
\hline $\begin{array}{l}\text { Perlu pembangunan dan perbaikan drainase di } \\
\text { Dusun Plumbon }\end{array}$ & 2 \\
\hline Perlu pembangunan showroom manik-manik & $\begin{array}{l}\text { Pembangunan dan perbaikan jembatan di Dusun } \\
\text { Juwok }\end{array}$ \\
\hline $\begin{array}{l}\text { Pembangunan dan perbaikan jembatan di Dusun } \\
\text { Pojok }\end{array}$ & 2 \\
\hline
\end{tabular}

\begin{tabular}{|l|l|}
\hline $\begin{array}{l}\text { Pembangunan dan perbaikan jembatan di Dusun } \\
\text { Gambang }\end{array}$ & 2 \\
\hline Pembangunan posyandu di Dusun Keturus & 2 \\
\hline Pembangunan Poskamlinng di Dusun Plumbon & 2 \\
\hline Pembangunan TPS di Dusun Gambang & 3 \\
\hline Pembangunan TPS di Dusun Juwok & 3 \\
\hline Pembangunan Jalan Linkungan & 3 \\
\hline Sanggar Remaja & 3 \\
\hline
\end{tabular}

Sumber: analisis penulis, 2016

Untuk program pembangunan fisik tersebut kemudian diberikan prioritas pengembangannya dimana masyarakat desa sendiri yang memutuskan urutan prioritas program usulan. Masing-masing warga desa diberikan opsi untuk memnentukan tiga program prioritas. Program prioritas 1 dan 2 akan dimasukkan pada RKP 2017 sedangkan program prioritas 3 dimasukkan pada RKP 2018.

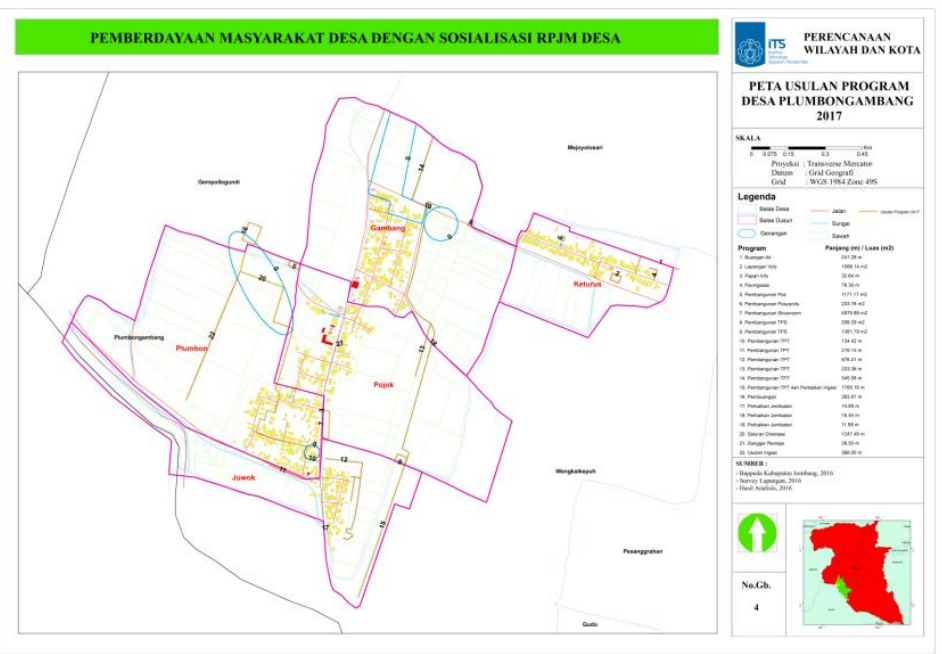

\section{Gambar 2. Peta Usulan Program Aspek Fisik}

Sumber: FGD Pengmas Plumbon

Gambang, 2016

Desa Gambang merupakan desa yang penggunaan lahannya masih didominasi oleh lahan persawahan. Di desa ini masih terdapat genangan di sawah dan di permukiman warga. Belum dilakukannya proses pengkerasan pada plengsegan (pinggir sungai) sehingga diperlukan pembangunan dan perbaikan drainase. 
Peningkatan jumlah penduduk setiap tahun diikuti dengan jumlah sampah yang dihasilkan oleh masyarakat, dan di Desa Plumbon Gambang belum memiliki tempat pembuangan sampah sementara, sehingga membutuhkan pengadaan Tempat Pembuangan Sementara.

Dusun keturus adalah dusun yang letaknya cukup jauh dari jalan utama desa, letak dusun yang harus melewati jalan persawahan membuat konsisinya kurang menjadi perhatian hingga menjadi rusak, sehingga membutuhkan perbaikan jalan lingkungan menuju Dusun Keturus. Selain itu kondisi posyandu di Dusun Keturus sudah rusak, sehingga warga membutuhkan pembangunan posyandu di Dusun Keturus. Sedangkan di Dusun Plumbon saluran irigasi dan drainase kurang lebarnya, dan Dusun Pojok dan Dusun Juwok saluran irigasi masih minim. Segingga masih dibutuhkan program perbaikan saluran irigasi /afur, dan diperlukan adanya pembangunan TPT. Serta diperlukan pembangunan jembatan di Dusun Gambangan sebagai jalur pertanian. Selain itu untuk menunjang kegiatan UMKM manik-manik di desa Plumbon Gambang masyarakat membutuhkan adanya pembangunan showroom manikmanik.

\section{KESIMPULAN DAN SARAN}

Pada dasarnya, masyarakat memiliki kemampuan dalam melakukan mengumpulan potensi dan permasalahan untuk mengembangkan desanya. Namun, diperlukan intervensi luar untuk mempercepat proses tersebut, khususnya dari akademisi. Intervensi tersebut berupa pengembangan masyarakat dengan pendekatan participatory rural planning (PRA) dengan bantuan teknik participatory mapping. Dengan pendekatan PRA dan bantuan teknik participatory mapping dalam masyarakat mampu menggambarkan lokasi-lokasi yang menjadi potensi, masalah, beserta pengembangan desa sebagai solusinya.
PRA merupakan salah satu alat untuk menggali potensi dan masalah, serta menentukan program atau solusi dalam mengatasi masalah yang ada di masyarakat. Dengan pendekatan PRA ini diharapkan masyarakat mampu mengaplikasikan pendekatan dalam proses penyusunan penataan ruang di desa, maupun dalam mencari program-program terbaik untuk setiap masalah yang dihadapi masyarakat, baik dalah aspek fisik, sosial maupun ekonomi.

\section{DAFTAR PUSTAKA}

[1] Anyaegbunam, C., Mefalopulos, P., \& Moetsa, T. (2004). Participatory Rural Communication Appraisal. Rome: FAO-UN.

[2] Bloor, M., Frankland, J., Thomas, M., \& Robson, K. (2002). Focus Group in Social Research. Wiltshire: The Cromwell Press Ltd.Cavestro, L. (2013). Participatory Rural Appraisal Concepts, Methodologies, and Techniques. Padova: Università degli Studi di Padova.

[3] Corbett, J. (2009). Good Practices in Participatory Mapping. Kelowna: Univesity of Biritsh Columbia Okanagan.

[4] Freudenberger, K. S. (2008). Rapid Rural Appraisal (RRA) and Participatory Rural Appraisal (PRA), A Manual for CRS Field Workers and Partners. Baltimore: Catholic Relief Services.

[5] Sumodiningrat, Gunawan. (1996) Pemberdayaan Masyarakat dan Jaring Pengaman Sosial. Jakarta, PT. Gramedia Pustaka Utama

[6] Waimbo, D. E. (2012). Pengembangan Pariwisata Berkelanjutan: Keterlibatan Masyarakat dan Peran Pemimpin Lokal di Kampung Sawinggrai Kabupaten Raja Ampat. Salatiga: UKSW.

[7] Kecamatan Gudo Dalam Angka 2016 